\title{
PRODUCTION OF BLOCKBOARD FROM SMALL ATHEL SLATS END-GLUED BY DIFFERENT TYPE OF JOINT
}

\author{
Morteza Nazerian ${ }^{1, \star}$, Vahid Moazami², Saeedreza Farokhpayam², Rahim Mohebi Gargari ${ }^{2}$
}

\begin{abstract}
This study evaluated the effect of joint type of short athel (Tamarix aphila) slats at three levels (butt joint, mitered joint, and half lap joint) in core layer veneer consisting of three wood species (Fir, Beech, and Oak). The joints were glued with PVAc and sandwiched by veneers with different ratios of melamine formaldehyde/urea formaldehyde resin $(0: 100,25: 75$, and 50:50) in glue line to determine the modulus of rupture in dry and wet conditions. It was found that the highest dry and wet modulus of rupture was obtained in specimens having slats jointed with half lap joint veneered with fir by using MF/UF ratio of 50:50. The maximum modulus of rupture parallel to the face/back veneer grain value in dry condition $(83,40 \mathrm{MPa})$ was observed to be higher than those values of modulus of rupture perpendicular to the face/back veneer grain $(65 \mathrm{MPa})$. However, the maximum modulus of rupture parallel to the face/back veneer grain value (53MPa) in wet condition were observed to be smaller than those values of modulus of rupture perpendicular to the face/back veneer grain value (56MPa).
\end{abstract}

Keywords: Beech, bending strength, blockboard panel, end to end half lap joint, Fir, melamineurea formaldehyde, Oak.

\section{INTRODUCTION}

Blockboard consists of a core of wood slats, which may be up to approximately $25 \mathrm{~mm}$ wide. These slats are arranged edge-to-edge and squeezed between two veneers of hardwood. This central layer (core) may contain defects undesirable for the face of the finished panels. The stiffness and composition of blockboard can be achieved by veneering via gluing, hot-pressing and using rotary-cut veneers. Generally, the orientation of veneer grain is set in perpendicular to the grain of core layer (Laufenberg et al. 2006). It is possible to produce strengthened glued lumber panels such as blockboard from low-grade logs by suitable dispersion of defect in all of the panel areas (Laufenberg 1982, Colak et al. 2007). Manufacturing process of these panels permit to eliminate or decrease negative effect of large defects such as knots, cracks and other strength-reducing characteristics dispersed throughout the cross-section in order to producing a more homogeneous product (Hing et al. 2005, Wang et al. 2003). Therefore, it is necessary to develop suitable production techniques for manufacturing panels by using locally available low-grade raw wood materials combined with veneer. In fact, production of panels can be encouraged due to the technical feasibility of using short length core blocks (which should maximize yield from low-grade and scrap wood) in the manufacturing of three-ply face-glued blockboard. In this way, the veneering and gluing process provide efficient use of forest resources via producing panels from low-grade wood logs with small dimensions (Colak et al. 2007).

To produce acceptable panels from short wood slats spliced together endwise used in the core layer, the role of strip joint type on the mechanical performance of blockboard coated with different wood 
species must be evaluated. The result showed that the type of joint in a layer, different species veneers and the adhesive spread had great effect on properties of bonded products. According to Ozcifci (2007), by increasing the joint angel of veneer in LVL production from 30 to $60^{\circ}$, the bending strength decreases to minimum, due to the reduction in the bonding area. Simultaneously, if it is assumed that blockboard is the one type of laminated particleboards which in slats form core layer, properties of panels can be affected by different wood species of veneers after the lamination process (Nazerian 2013). In fact, hardwood and softwoods, both as species groups and as species within a group, have different porosity. This causes variation in the amount and direction of adhesive penetration (Vick 1999).

The influence of tensile and compression loading on the strength of corner V-nail and dovetail joints, with and without adhesive were studied for fiberboard and particleboard (Taghiyari et al. 2017). It was determined that V-nails are recommended for craftsmen in case adhesive is used. However, dovetail joints provide higher strength if the production process necessitates not to use adhesive in joints.

Effectiveness of finger jointing in utilizing mango wood sections for various end uses like furniture was evaluated (Kumar et al. 2015). It was found that the modulus of elasticity of the sections joined showed significantly better values than that of unjointed clear wood sections. Under compression, the parameters of the jointed sections were either similar or better than those of the unjointed clear wood sections.

It was demonstrated that physical and mechanical properties of coated panel can be improved with different coatings (Norvydas and Minelga 2006, Nemli et al. 2001). According to Nazerian (2013), the bending strength is correlated to the wood veneer species covered panels, and consequently, to the adhesive penetration and to the amount of adhesive applied on the veneer surface and the panel.

The literature had only limited information on the feasibility of using low-cost solid wood in blockboard panel production. Moazami and Nazerian (2014) investigated the effect of end-to-end joint types of short slats on the modulus of rupture and modulus of elasticity of the blockboard. It was determined that the type of joint had the effect on the modulus of rupture (MOR) and modulus of elasticity (MOE), significantly, so the panels having short slots jointed with end-to-end half lap joint in core layer had the highest strength properties. According to Morrell (2002), blockboard manufacturing facilities to use low-cost solid wood strips that may contain defects undesirable for the face of the finished panels and to produce lower cost utility types of boards. Besides, one of the main advantages of blockboard over others laminated wood products such as plywood is that the core layer of the board is made up of thick sections of wood. Accordingly, application of few number of thick layers or slats in core reduces cost and manufacturing time (Laufenberg et al. 2006). The aim of this study was to determine the effects of joint type of athel wood slat used in core layer, veneer wood species coating core layer and resin type used in glue line on the bending strength of blockboard.

\section{MATERIALS AND METHODS}

In order to determine the effect of load direction on the bending strength (parallel to the face/back veneer grain and perpendicular to the face/back veneer grain) of panels in dry and wet conditions, four series of blockboards with three replicates (a total of 324), $500 \mathrm{~mm} \times 90 \mathrm{~mm} \times 15 \mathrm{~mm}$, were manufactured from clean 1-mm-thick rotary-peeled veneers of fir (Abies nordmanniana), oak (Quercus castaneifolia) heartwood, and beech (Fagus orientalis), the three species used extensively in the plywood industry. The core layer consisted of athel (Tamarix aphylla) slats. The fir, beach and oak veneers and the athel slats were then conditioned in a conditioning chamber at $20 \pm 2^{\circ} \mathrm{C}$ and relative humidity of $65 \pm 5 \%$ for at least one month to achieve the final moisture content of $12 \pm 1 \%$ prior to board producing. Grain orientation on cross section of core layer slats was parallel to the growth rings.

For the core layer, short slats of athel were glued side-to-side with a polyvinyl acetate (PVAc) resin and pressed at 0,1 to $0,2 \mathrm{MPa}$ at $40^{\circ} \mathrm{C}$ for $24 \mathrm{~h}$. In order to join the end of two short slats, three type of end joints were used: end-to-end butt joint (at a right angle), end-to-end mitered joint (at a $30^{\circ}$ angle), and end-to-end half lap joint. After end-jointing, the lumber was machined with an abrasive planer to 
obtain slats with dimensions of $500 \mathrm{~mm} \times 30 \mathrm{~mm} \times 13 \mathrm{~mm}$. The prepared end-to-end jointed slats used in the core layer of samples are shown in Figure 1.

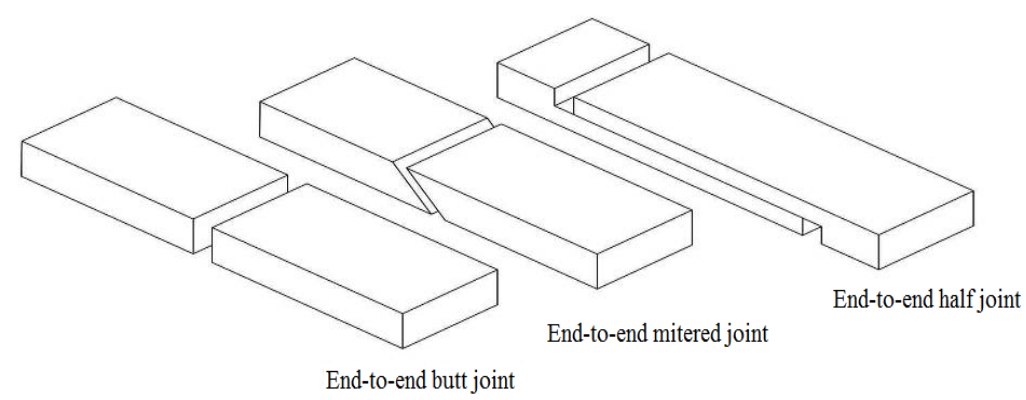

Figure 1. Three types of end-to-end joints used in core layer of the blockboard.

Three types of adhesive consisting of different ratios of melamine formaldehyde/urea formaldehyde resin $(0: 100,25: 75$, and 50:50) were used to bond the face and back veneers to the 13-mm athel core. The adhesives, with a solids content of $70 \%$, were uniformly separated onto one side of the face veneers at approximately $90 \mathrm{~g} / \mathrm{m}^{2}$ by putty spittle. The end-to-end jointed athel core layer was then sandwiched between two veneers and pressed at $100 \mathrm{bar}$ and $140{ }^{\circ} \mathrm{C}$ for $2 \mathrm{~min}$ in a hot press. Three specimens were each prepared with slats parallel to the outer layers (Figure 2a) and three specimens with slats perpendicular to the outer layers (Figure $2 b$ ).

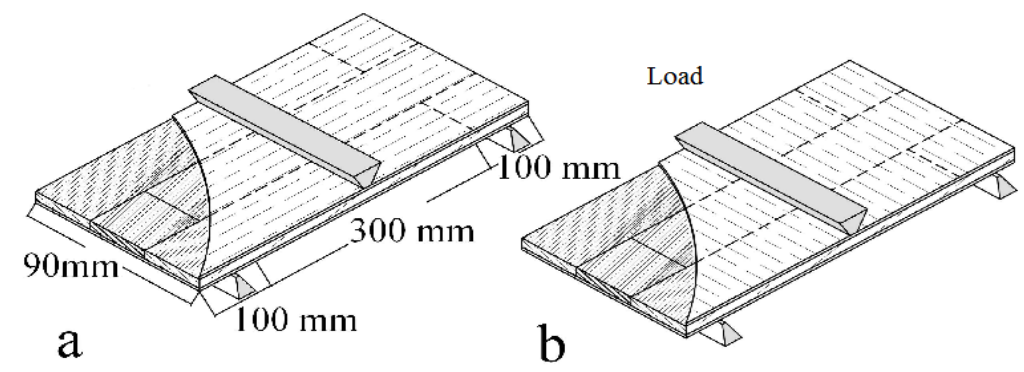

Figure 2. Specimens with slats (a) parallel to the outer layers and (b) perpendicular to the outer layers for the bending strength test.

To determine the density and panel flexural properties (modulus of rupture, MOR) before and after immersion in distilled water for $24 \mathrm{~h}$, the specimens $(500 \mathrm{~mm} \times 90 \mathrm{~mm} \times 15 \mathrm{~mm})$ were conditioned for at least 3 weeks at $20{ }^{\circ} \mathrm{C} \pm 2{ }^{\circ} \mathrm{C}$ and $65 \% \pm 5 \%$ relative humidity prior to mechanical testing. Samples for determination of density and density profile were taken from an unbroken portion of the flexural samples from each panel and cut to the dimensions of $90 \mathrm{~mm} \times 90 \mathrm{~mm} \times 15 \mathrm{~mm}$. Density of each samples was determined by mass per unit volume at the moisture content of $12 \pm 1 \%$. The mechanical tests were performed on a Hounsfield Materials testing machine (H25KS, UK) equipped with a $25 \mathrm{kN}$ load cell. Moreover, Prior to MOR testing, the vertical density profiles of the panels were determined using a density profiler (MCB 65C-0.2W, Spellman, SicoScan, Siempelkamp, Germany) by means of $\mathrm{X}$-ray transmitted through the sample along the thickness.

Data for each test were statistically analyzed by analysis of variance (ANOVA) at a 95\% confidence 
interval (alpha $=0,05)$ to examine the effects of manufacturing parameters (joint type of strip in core layer, wood species veneer coating core layer, and resin type in glue line) on MOR of the blockboard. Duncan's multiple range test at a 5\% level of probability determined the significant differences among experimental panels using SPSS statistical software package (IBM, SPSS v.16.0, USA). The t-test was used to determine the statistical differences between the bending strength parallel to the face/ back veneer grain and perpendicular to the face/back veneer grain according to applied variables in production.

\section{RESULTS AND DISCUSSION}

\section{Density of panels}

Density mean values, compaction ratio and density profile of samples before and after gluing process and press are shown in Table 1 and Figure 3. Air-dry density values ranged between 610 and $830 \mathrm{~kg} / \mathrm{m}^{3}$. Panels covered with oak and beech veneer had the highest density values $(830$ and $810 \mathrm{~kg} /$ $\mathrm{m}^{3}$, respectively), however, it seems that big variations in density was experienced in the panels with fir ranging from 610 to $800 \mathrm{~kg} / \mathrm{m}^{3}$.

Table 1. Density mean values and compaction ratio of samples before and after press.

\begin{tabular}{lccc}
\hline & & & \\
& Fir & Beech & Oak \\
Variables & & & \\
\hline Density before gluing, $\mathrm{kg} / \mathrm{m}^{3}$ & 610 & 680 & 730 \\
\hline Density after pressing, $\mathrm{kg} / \mathrm{m}^{3}$ & 800 & 810 & 830 \\
\hline Compaction ratio, $\%$ & 0,31 & 0,19 & 0,13 \\
\hline
\end{tabular}

In blockboard production, slats and veneers are laminated together under pressure. Although, the same processing conditions were chosen in press, with respect to different species of wood veneers used in outer surfaces and different compaction ratio of panels created during the press, board densities and their profiles were varied (Figure 3).

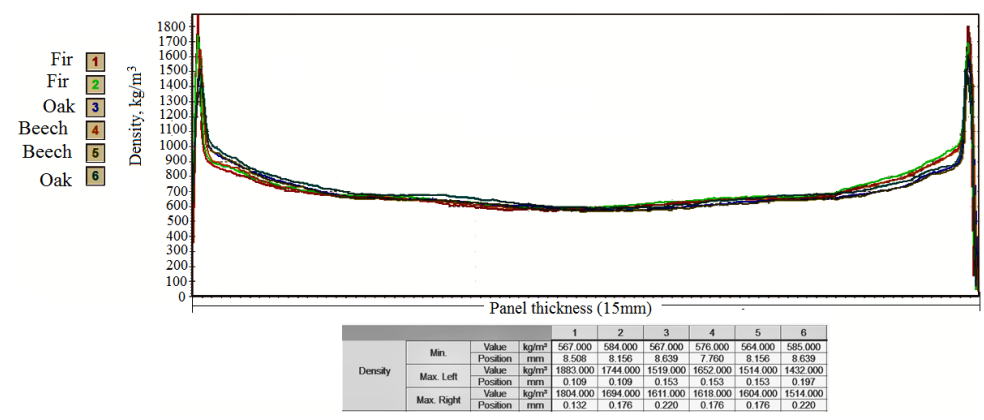

Figure 3. Density profile of panels veneered with fir, beech and oak. All three type panels were produced using MF/UF ratio of 25:75.

When a panel was veneered with fir, the tendency to increase in density was more significant than with beech and oak. Similarly, the compaction ratio of panels veneered with fir was higher than others. With respect to that, the thickness of the panels with the pressure applied depending on wood species, 
the reason for this stronger tendency to increase the density is related to the thickness loss of these panels due to the compression rate during hot pressing, and also an increase in resin-to-wood ratio.

\section{Bending strength}

To determine the effect of end-to-end joint type on the bending strength of panels, the bending strength of slats connected with three type of end-to-end joints (butt joint, mitered joint and half lap joint) was examined (Table 2).

Table 2. Modulus of rupture of athel slats jointed with different end-to-end joints used in core layer of blockboard.

\begin{tabular}{ll}
\hline Type of joint & MOR, MPa \\
\hline Butt joint, & $23( \pm 2,00)$ \\
Mitered joint & $27( \pm 2,40)$ \\
Half lap joint & $40( \pm 1,76)$ \\
\hline
\end{tabular}

MOR of the tested slats fluctuated from 23 to 40MPa. Slats jointed with half lap joint showed a higher MOR values (40MPa), while samples jointed with butt joint showed the lowest value (23MPa). These results are in conformance with the studies in the literature (River 1994, Kapica 1986).

The sample jointed with mitered joint showed intermediate value $(27 \mathrm{MPa})$. The bending strength (MOR) parallel and perpendicular to the face/back veneer grain in dry and wet conditions are presented in Table 3 and Figure 4, Figure 5, Figure 6, Figure 7.

Table 3. Bending strength of experimental panels (MOR), MPa.

\begin{tabular}{|c|c|c|c|c|c|c|}
\hline \multirow{2}{*}{ Joint type } & \multirow{2}{*}{$\begin{array}{l}M F / U F \\
\text { ratio }\end{array}$} & Veneer & \multicolumn{2}{|c|}{ Modulus of rupture, $\mathrm{MPa}$} & \multirow[b]{2}{*}{$\mathrm{MOR}_{\perp_{\mathrm{wet}}}$} & \multirow[b]{2}{*}{$\mathrm{MOR}_{\| \text {wet }}$} \\
\hline & & & $\mathrm{MOR}_{\perp_{\mathrm{dry}}}$ & $\mathrm{MOR}_{\| \mathrm{dry}}$ & & \\
\hline \multirow{10}{*}{ Butt } & $0 / 100$ & Fir & 40,7 & 49,7 & - & - \\
\hline & $0 / 100$ & Beech & 36,2 & 46,9 & - & - \\
\hline & $0 / 100$ & Oak & 34,2 & 45,0 & - & - \\
\hline & $25 / 75$ & Fir & 44,2 & 53,4 & 33,2 & 24,3 \\
\hline & $25 / 75$ & Beech & $\begin{array}{l}44,2 \\
38,0\end{array}$ & $\begin{array}{l}53,4 \\
48,2\end{array}$ & 27,2 & 20,1 \\
\hline & $25 / 75$ & $\begin{array}{l}\text { Oak } \\
\text { Fir }\end{array}$ & 35,7 & 46,0 & 24,7 & 17,5 \\
\hline & $50 / 50$ & Fir & 50,7 & 56,1 & 38,7 & 28,1 \\
\hline & $50 / 50$ & Beech & 47,8 & 54,0 & 36,1 & 26,1 \\
\hline & $50 / 50$ & Oak & 38,4 & 51,6 & 27,1 & 23,6 \\
\hline & $0 / 100$ & Fir & 48,1 & 57,8 & - & - \\
\hline \multirow{7}{*}{ Mitered } & $0 / 100$ & Beech & 44,8 & 55,6 & - & - \\
\hline & $0 / 100$ & $\begin{array}{l}\text { Oak } \\
\text { Fir }\end{array}$ & 39,7 & 52,8 & - & - \\
\hline & $25 / 75$ & Fir & 51,2 & 61,8 & 40,0 & 33,3 \\
\hline & $25 / 75$ & Beech & 43,5 & 56,2 & 32,2 & 27,5 \\
\hline & $25 / 75$ & Oak & 40,3 & 54,8 & 29,9 & 26,2 \\
\hline & $50 / 50$ & Fir & 57,2 & 66,0 & 46,2 & 38,1 \\
\hline & $50 / 50$ & Beech & 49,9 & 61,0 & 38,2 & 34,1 \\
\hline \multirow{10}{*}{ Half lap } & $50 / 50$ & $\begin{array}{l}\text { Oak } \\
\text { Fir }\end{array}$ & 46,4 & 59,1 & 35,1 & 31,0 \\
\hline & $0 / 100$ & Fir & 54,1 & 63,5 & - & - \\
\hline & $0 / 100$ & Beech & 42,5 & 63,4 & - & - \\
\hline & $0 / 100$ & Oak & 42,2 & 55,3 & - & - \\
\hline & $25 / 75$ & Fir & 57,3 & 68,1 & 46,2 & 40,1 \\
\hline & $25 / 75$ & Beech & 53,3 & 65,0 & 42,1 & 37,1 \\
\hline & $25 / 75$ & Oak & 45,2 & 62,5 & 37,0 & 34,0 \\
\hline & $50 / 50$ & Fir & 65,0 & 83,4 & 56,1 & 53,0 \\
\hline & $50 / 50$ & Beech & 61,2 & 70,1 & 50,2 & 42,2 \\
\hline & $50 / 50$ & Oak & 50,1 & 67,0 & 43,1 & 39,0 \\
\hline
\end{tabular}




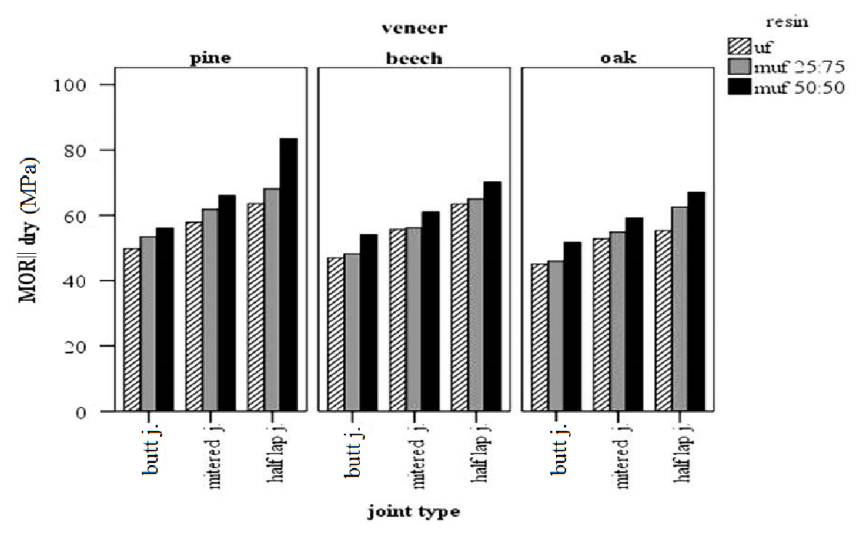

Figure 4. The influence of different joint type of slats in core layer, MF/UF resin ratio in glue line and veneer species veneering core layer of panels on bending strength parallel to the face/back veneer grain value in dry condition $\left(\mathrm{MOR} \|_{\text {dry }}\right)$.

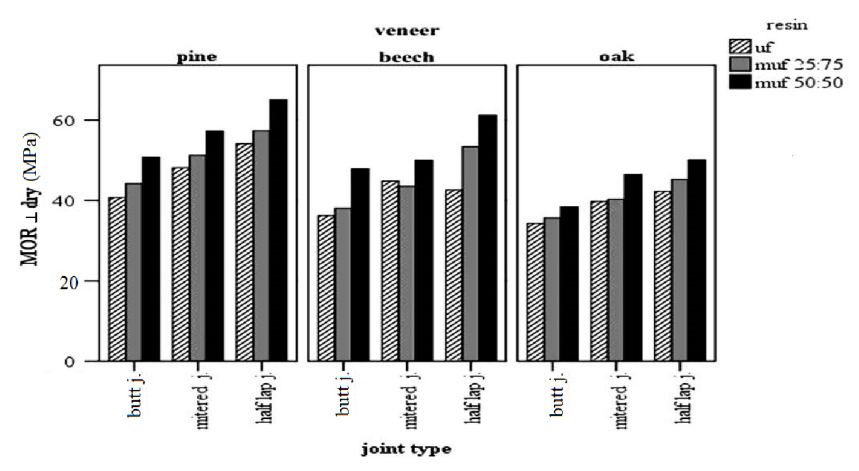

Figure 5. The influence of different joint type of slats in core layer, MF/UF resin ratio in glue line and veneer species veneering core layer of panels on bending strength perpendicular to the face/back veneer grain value in dry condition $\left(\mathrm{MOR}_{\mathrm{dry}}{ }_{\mathrm{dry}}\right)$.

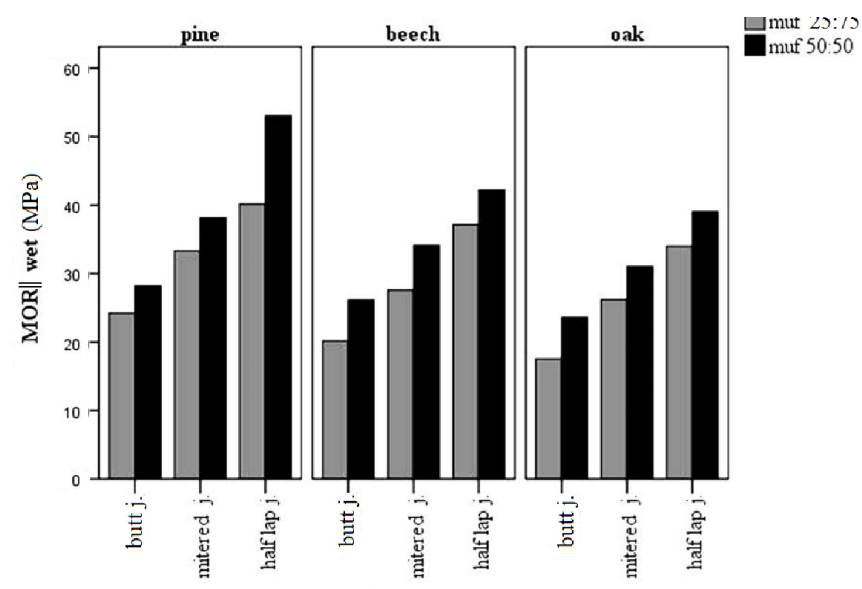

Figure 6. The influence of different joint type of slats in core layer, MF/UF resin ratio in glue line and veneer species veneering core layer of panels on bending strength parallel to the face/back veneer grain value in wet condition $\left(\mathrm{MOR} \|_{\text {wet }}\right)$. 


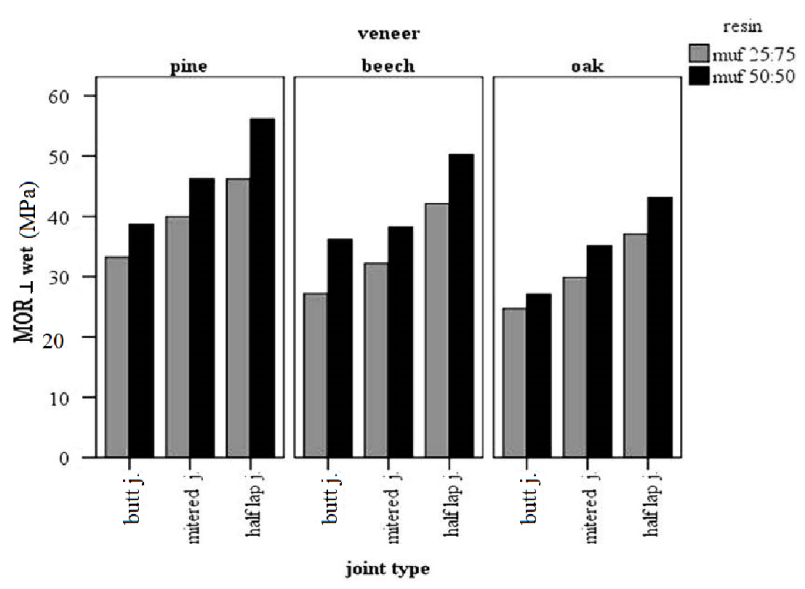

Figure 7. The influence of different joint type of slats in core layer, MF/UF resin ratio in glue line and veneer species veneering core layer of panels on bending strength perpendicular to the face/back veneer grain value in wet condition $\left(\mathrm{MOR} \perp_{\text {wet }}\right)$.

A multifactor variance analysis results displaying whether there are any differences between the modulus of rupture (MOR) values is given in Table 4. It was determined that the interaction between the main variables is significant with the $95 \%$ and $99 \%$ confidence based on the ANOVA analysis. Duncan test was used to show the difference determined with ANOVA. It was determined that MORs were affected by the type of joint in core layer (butt joint (at a right angle), mitered joint (at $30^{\circ}$ angle) and half lap joint, veneer species (oak, beech and fir) and ratio level of MF/UF resin in glue line (0/100, $50 / 50$ and $100 / 0)$, statistically.

Table 4. Statistical analysis of bending strength of blockboard produced with different variables.

\begin{tabular}{llllll}
\hline Property & Symbol & $\mathrm{MOR}_{\perp_{\text {dry }}}$ & $\mathrm{MOR}_{\| \text {dry }}$ & $\mathrm{MOR}_{\perp_{\text {wet }}}$ & $\mathrm{MOR}_{\| \text {wet }}$ \\
\hline Joint t. & $\mathrm{A}$ & $* *$ & $* *$ & $* *$ & $* *$ \\
MF/UF resin & $\mathrm{B}$ & $* *$ & $* *$ & $* *$ & $* *$ \\
Joint t. $*$ MF/UF resin & $\mathrm{AB}$ & $* *$ & $* *$ & $* *$ & $* *$ \\
Veneer S. & $\mathrm{C}$ & $* *$ & $* *$ & $* *$ & $* *$ \\
Joint t. ${ }^{*}$ Veneer S. & $\mathrm{AC}$ & $* *$ & $* *$ & $* *$ & $* *$ \\
MF/UF resin * Veneer S. & $\mathrm{BC}$ & $* *$ & $* *$ & $* *$ & $* *$ \\
Joint t. $*$ MF/UF resin*Veneer S. & $\mathrm{ABC}$ & $* *$ & $* *$ & $* *$ & $* *$ \\
\hline Note: ${ }^{*}$, significant difference at the $1 \%$ level $(\mathrm{p} \leq 0,01 \%)$. & & & &
\end{tabular}

Specimens bonded with half lap joint (at a constant ratio of MF/UF resin and same veneer) showed a higher dry and wet MOR $\perp$ and MOR $\|$ values $(52,34 ; 66,50 ; 30,56$ and 27,30MPa respectively), and specimens bonded with butt joint showed the lowest values $(40,68 ; 50,12 ; 20,80$ and $15,55 \mathrm{MPa}$ respectively).

Dry and wet MOR $\perp$ and MOR $\|$ of specimens were affected by the MF/UF ratios. At a constant wood veneer coating slats and same joint type, specimens bonded with MF/UF ratio of 50:50 showed a higher MOR $\perp$ and MOR $\|$ dry and wet values $(51,58 ; 63,17 ; 41,25$ and $35,06 \mathrm{MPa}$, respectively), and specimens bonded with MF/UF ratio of 0:100 showed the lowest values(42,5;54,4; 0 and $0 \mathrm{MPa}$, respectively).

At a constant ratio of MF/UF resin and same joint type, using fir veneer resulted in higher values of $M O R \perp_{\text {dry, }}$ MOR $\|$ dry, MOR $\perp_{\text {wet }}$ and MOR $\|$ wet $(52,07 ; 62,22 ; 28,95$ and $24,12 \mathrm{MPa}$ respectively), while, specimens veneered with oak showed the lowest values (from 54,95 to $19,06 \mathrm{MPa}$ ).

According to the results (Table 3), MORdry in both parallel and perpendicular to the face/back 
veneer grain of all panels increased with a reduction in panel density by using fir veneer and an increase in MF/UF ratio in glue line. According to the Duncan Multiple Range Classification results, bending strength of the boards were improved and sited in maximum level when the half lap joint, fir veneer and $\mathrm{MF} / \mathrm{UF}$ resin ratio of 50:50 in glue line were used. Therefore, it may be possible to manufacture stronger boards by favorable choice of variables involved in this study.

When the t-test was performed to determine differences between the bending strength parallel and perpendicular to the face/back veneer grain, with a probability of a $1 \%$ level, there was a statistical difference between the $t$-values of modulus of ruptures. It means that the bending strength of blockboard is indeed highly depended on the loaded direction to the grain of face plies. Testing perpendicular to the grain orientation of face plies showed a significantly lower MOR than those tested parallel to the grain orientation in dry condition. This could be attributed to the fact that the bending strength of wood massive along the grain orientation is higher than across the grain orientation. However, MOR perpendicular to the face/back veneer grain values were significantly higher than those tested parallel to the face/back veneer grain in wet condition. This could be due to the fact that glue distribution was not as uniform during the panel production.

During a bending test, maximum stress occurs on compression and tensile sides. In transverse direction, strength is related to fiber-to-fiber bonding with the middle lamella acting as the adhesive. Due to lower stiffness and strength of lignin compounds, failure can occur easily in the lamella (enriched by lignin) of the face-back wood veneer (Tuttle 2003) covering the perpendicular blockboard.

Moreover, Covalent bonds of cellulose microfibrils are the reason of high bending strength of wood veneer in the longitudinal direction (along the grain orientation) compared to the transverse direction (across the grain orientation) which has hydrogen bonds. Hence, it's easier to split a wood veneer of surface layers with grain (separating the lignin) than breaking it across the grain (separating the cellulose fibers). Cellulose chain is the strongest polymer that is abundant in wood and thus, it is largely responsible for the strength in veneers because of its high degree of polymerization and linear orientation. Therefore, fibers of veneers containing cellulose carry the main load in parallel with face/ back veneer grain. (Winandy and Rowell 2005)

It seems that stress value near the center of the lap length was found to be gradually approaching to zero (in third case). However, in the second case of jointed slats $\left(30^{\circ}\right)$, although the contact surface between two slats glued together provides a stronger resistance and values of stress peak decreases with increasing lap length comparing with first case $\left(90^{\circ}\right)$, transition of overlapping surface from center to surface layers causes to increase maximum stress in second case. Moreover, number of fiber and vessel cross sections in first and second case was higher than the third. Hence, adhesive would have penetrated deeper into open fibers and vessels along the grain. This causes a reduction in the amount of resin at glue line and have a negative effect on the bonding strength (Vick 1999).

It was demonstrated that the bending strength of panels veneered with different species could be affected by different ways. Previous studies had also shown that mechanical properties of panels were affected by certain factors such as wood species of veneers, differently (Nazerian 2013, Norvydas and Minelga 2006). At first, these factors effect on density profile (peak and core density) of panels. The density profile is highly dependent on the target thickness in press.

With decreasing the thickness during the press, the gradient of profile density in thick of panels could be sharper, so higher peak density and a slightly lower core density can be expected (Figure 3). It is well known that a load bearing member with highly densified surface would be better than that with homogeneous structure as far as bending performance is concerned. From this point of view, the modulus of rupture is dependent on the maximum load that can be resisted by the member; panels that have a higher surface density were able to carry a higher load before failing during static bending resulting in higher MOR values than the panels with homo-profile panels. Besides, deeper penetration of resin into microstructure of fir veneer than beech and oak increases peak density and surface area of contact between adhesive and wood for more effective mechanical interlocking and chemical bond. If an adhesive penetrates deeply enough into wood, with respect to increasing the density of surface layers and becoming rigid enough upon curing, the modulus of rupture of panels coated with fir veneer can be expected to exceed the MOR values of panels veneered with beech or oak. 


\section{CONCLUSIONS}

Based on this study, the following conclusion could be drawn for the properties of blockboard:

It was revealed that the performance of blockboard is highly dependent upon the type of slats end-to-end joint used in core layer, wood species veneer which has coated slats and MF/UF resin ratio in glue line. When using end-to-end half lap joint to connect slats in core layer, the dry and wet static bending strength (MOR) increased. Specimens with slats connected with butt joints however, exhibit low values of MOR. This result can be explained by sufficient resistance against tensions due to the existence of neutral axis with much more interfacial surface area in half lap joint than butt and mitered joints, less fiber and vessel cross sections of wood at the end parts of the cut, despite the fact that miter joint increases the area of the adhesive surface.

Compared to panels veneered with beech and oak, blockboard veneered with fir exhibits stronger performance due to the higher peak density and compaction ratio, in spite of higher mean density of beech or oak blockboard. In fact, higher percentage of increment in bending strength was obtained when board veneered by fir species with a higher MF content was used in the glue line.

Dry and wet bending strength of the specimens was affected by type of loading, differently. Generally, specimens with slats oriented parallel to the face/back veneer grain seem to be stronger than the specimens with slats perpendicular to the face/back veneer grain in dry condition. However, MOR of specimens with slats perpendicular to the face/back veneer was found to be significantly higher than those tested parallel to the face/back veneer grain in wet condition.

\section{REFERENCES}

Laufenberg, T.; Ayrilmis, N.; White, R. 2006. Fire and bending properties of blockboard with fire retardant treated veneers. Holz als Roh-und Werkstoff 64: 137-143.

Laufenberg, T. 1982. Exposure effects upon performance of laminated veneer lumber and glulam materials. Forest Products Journal 32(5): 42-48.

Colak, S.; Colakoglu, G.; Aydin, I. 2007. Effects of log steaming, veneer drying and aging on the mechanical properties of laminated veneer lumber (LVL). Building Environment 42: 93-98.

Hing, P.S.; Paridah, M.T.; Zakiah, A. 2005. Edgewise bending properties of LVL: effects of veneer thickness and specie In: The proceeding of USM-JIRCAS joint international symposium, lignocelluloses material of the millennium. 3-5 April. 2005. Washington State University, Washington, USA, p. 3-14.

Wang, X.; Ross, R.J.; Brashaw, B.K.; Verhey, S.A.; Formsan, J.W.; Ericson, J.R. 2003. Flexural Properties of laminated veneer lumber manufactured from ultrasonically rated red maple veneer. Forest Products Laboratory 2003; FPL-RN-0288.

Ozcifci, A. 2007. Effects of scarf joints on bending strength and modulus of elasticity to laminated veneer lumber (LVL). Building Environment 42:1510-1514.

Nazerian, M. 2013. The lamination influence on properties of agro-based particleboard. Wood Material Science and Engineering 8(2): 129-138.

River, B.H. 1994. Fracture of adhesive-bonded wood joints. Pizzi, A. and Mittal, K.L. eds. Handbook of adhesive technology. New York Marcel Dekker, Inc. pp 151-177. 
Kapica, L. 1986. Glulam elements for upholstered furniture frames. Holztechnologie 27(3): 127-129.

Vick, C.B. 1999. Wood handbook-Wood as an engineering material. Chapter 9, Adhesive Bonding of Wood Materials. Forest Products Laboratory. Madison, WI: U.S. Department of

Agriculture, Forest Service, Forest Products Laboratory. 1999; 463 p.

Taghiyari, H.R.; Ghofrani, M.; Ghamsari, F.A. 2017. Effects of adhesive and loading directions on the load-carrying capacity of V-nails. Maderas-Cienc Tecnol 19(1): 113-129.

Kumar, V.S.K.; Sharma, C.M.; Gupta, S. 2015. Compression and flexural properties of finger jointed mango wood sections. Maderas-Cienc Tecnol 17(1): 151-160.

Norvydas, V.; Minelga, D. 2006. Strength and stiffness properties of furniture panels covered with different coatings. Material Science 12(4): 328-332.

Nemli, G.; Kalaycioglu, H.; Alp, A. 2001. Suitability of date palm (Phoenix dactyliferia)

branches for particleboard production. Holz als Roh und Werkstoff 59(6): 411-412.

Moazami, V.; Nazerian, M. 2014. Effect of Joint type in core layer and wood species veneer on surface layers on mechanical properties of blockboard. Iranian Journal of Forest and Wood Products 68(3): 573-590 (in Persian).

Morrell, J.J. 2002. Wood-based composites: what have we learned? International Biodeterioration and Biodegradation 49: 253-258.

Tuttle, M.T. 2003. Structural Analysis of Polymeric Composite Materials. 2nd ed. Taylor \& Francis, Boca Raton, Florida. 647pp.

Winandy, J.E., Rowell, R. 2005. Chemistry of wood strength. In: Rowell R (ed) Handbook of wood chemistry and wood composites. Taylor \& Francis, Boca Raton London New York Singapore, pp 303-347. 